Justyna Żukowska-Łyko

(Uniwersytet Wrocławski

Wydział Nauk Historycznych i Pedagogicznych)

\title{
ŻYDZI W STARGARDZIE POWIATU SZADZKIEGO W XIX I XX WIEKU - UCHWYCENIE JUŻ NIEOBECNYCH
}

$\mathrm{P}$ rzedmiotem refleksji w niniejszym artykule są Żydzi na obszarze dzisiejszego Pomorza Zachodniego w powiecie szadzkim ze szczególnym uwzględnieniem Stargardu w okresie XIX i XX wieku.

Dlaczego akurat taka cezura? Wiek XIX przy całym swym postępie i nowoczesności był również czasem odrodzenia religijnego, katolickiego, protestanckiego, żydowskiego. W przypadku judaizmu dotyczyło to Haskali i judaizmu reformowanego, który miał swój początek w Niemczech w XIX wieku. To, co się działo na polu historycznym, kulturowym, społecznym, politycznym czy naukowym całkowicie odmieniło kształt świata. Życie ludzi, relacje między narodami, zmieniły się nie tylko za sprawą wojen, ale także w wyniku rewolucji przemysłowej, demograficznej, rozwoju cywilizacyjnego i urbanistycznego. Wszystkie te procesy, nakładające się na siebie, spowodowały powstanie nowej jakości funkcjonowania, korelacji w społeczeństwie i państwie. Historia narodu żydowskiego i jego relacji z innymi narodami w ciągu wieków kształtowała nie tylko ekonomicznie, ale i społecznie obszar, na którym osiedlała się. To właśnie wiek XIX był najintensywniejszym czasem kształtowania się takich pojęć, jak naród, społeczeństwo i państwo. Często wiek XIX jest nazywany stuleciem Prus. Opinia ta jest wynikiem badań naukowców w świetle uwarunkowań politycznych, przemian społecznych i rozwoju kultury ${ }^{1}$. Stargard leżący na terenie Pomorza Zachodniego było terenem należącym do państwa pruskiego (a po zjednoczeniu do Niemiec), na którym można było zaobserwować wszystkie wyżej wymieniane tendencje, sytuacje i procesy.

Od niedawna w dyskursie naukowym można zaobserwować tendencję do opisywania dziejów Żydów nie w skali całych państw, ale mikroregionów ${ }^{2}$. Punkty ciężkości analiz historyków i badaczy przenoszą się co pewien czas z jednych

${ }^{1}$ T.C. W. Blanning, Wstęp: koniec starego porzadku, [w:] Zarys historii Europy XIX wiek, pod red. tegoż, Warszawa 2004, s. 4.

${ }^{2}$ M. Pielka, Ekscesy antyżydowskie na Pomorzu w latach 80. XIX wieku, „Midrasz. Pismo żydowskie", nr 1. (171) styczeń/luty 2013, s. 38. 
obszarów badawczych na drugie. I tak jak sygnalizował Mateusz Pielka w swoim artykule, tendencja do opisywania mikroregionów, zaowocowała tym, że to właśnie w przeciągu ostatnich 20 lat, powstało większość prac o tematyce żydowskiej na Pomorzu.

Pierwsze przypadki osadnictwa żydowskiego na Pomorzu możemy zanotować w XIII w. Jednym z najczęstszych zajęć Żydów był handel. I też pierwszymi Żydami docierającymi na te tereny byli kupcy ${ }^{3}$. Dopiero po wojnie trzydziestoletniej i wyludnieniu, jakie ona spowodowała, został zainicjowany proces osadnictwa żydowskiego w wyznaczonych miejscowościach. Choć nastawienie Prus do ludności żydowskiej i jej osadnictwa można nazwać liberalnym, to dopiero de facto wiek XIX przyniósł znaczącą zmianę w położeniu prawnym i w osadnictwie Żydów na Pomorzu4

Specyficzne położenie społeczności żydowskiej na Pomorzu względem innych państw europejskich było spowodowane polityką pruską i szeroko zakrojonymi reformami wewnątrz kraju. Głównie z tej przyczyny to właśnie w Prusach najintensywniej i najszybciej przebiegał proces akulturacji i asymilacji ${ }^{5}$. Poruszając zagadnienie emancypacji Żydów i przemian w prawnym położeniu ludności wyznania mojżeszowego, nie tylko na terenie Pomorza Zachodniego, ale i Prus w ogóle, należy zwrócić uwagę na szerokie tło uwarunkowań społecznych, politycznych i historycznych, które jednak na potrzeby tego artykułu nie będą szerzej omawiane ${ }^{6}$.

${ }^{3}$ H. Zaremska, Żydzi osiedlali się tam, gdzie mogli pozostać Żydami, dostępne w Internecie: http://dzieje.pl/aktualnosci/prof-zaremska-zydzi-osiedlali-sie-tam-gdzie-mogli-pozostac-zydami (dostęp: 30.10.2014).

${ }^{4}$ K. Kozłowski, Informacja o losach Żydów na Pomorzu Zachodnim od XIII wieku. Kilka stów o celach $i$ uczestnikach sesji, [w:] Żydzi szczecińscy - tradycja $i$ współczesność: materiały z sesji naukowej, 27 czerwca 2003 r., pod red. K. Kozłowski, J. Mieczkowski, Szczecin 2004, s. 19, 20.

${ }^{5}$ Przyczyną używania takich terminów było przejęcie ich z innych dziedzin i dyscyplin naukowych, jak biologia czy nauki społeczne. Jednak, jak się okazało w późniejszym czasie, biologiczne pojęcia, zastosowane na innym gruncie, nie były kompatybilne z omawianym zjawiskiem. Na przełomie XIX i XX wieku pojawiły się różne definicje asymilacji. W jaki sposób sami Żydzi definiowali, czy też postrzegali zjawisko asymilacji? Znaczące będzie samo thumaczenie słowa asymilacja, z hebrajskiego hitbolelut, co tłumaczymy jako ,wynarodowienie”. Co za tym idzie, używanie tego słowa w tekstach syjonistów od razu nabierało negatywnego wydźwięku. Przy czym, nie podkreślano możliwości rozwoju, jakie niosła ze sobą asymilacja (np. ekonomiczne, polityczne itp.), a podkreślała ów aspekt wynarodowienia. Za: A. Jagodzińska, Pomiędzy. Akulturacja Żydów Warszawy w drugiej połowie XIX wieku, Wrocław 2008, s. 9.

${ }^{6}$ Emancypację Żydów na terenie Niemiec można podzielić na kilka etapów, uwzględniając przy tym stronę samej społeczności żydowskiej, jak również otoczenia. Ponadto zjawisko badań historycznych, obejmujących swym zasięgiem emancypację Żydów pruskich, dzieli się na poszczególne etapy, czy też fale. Szerzej na ten temat piszą: L. Ziątkowski we wprowadzeniu do: Między niemożliwym a koniecznym. Reformy państwa pruskiego w końcu XVIII i na początku XIX wieku, a proces równouprawnienia Żydów ze szczególnym uwzględnieniem sytuacji na Śląsku, Wrocław 2007 oraz A. Eisenbach we wprowadzeniu oraz założeniach badawczych w: Emancypacja Żydów na ziemiach polskich 1785-1870 na tle europejskim, Warszawa 1988. 
Powiat szadzki, był obszarem, który terytorialnie znajdował się na terenie kolejno: Prus, Cesarstwa Niemieckiego, Republiki Weimarskiej i wreszcie III Rzeszy. W wyniku postanowień kongresu wiedeńskiego (z dnia 30 IV 1815 r.), od dnia 1 I 1818 r. powiat szadzki przynależał do rejencji szczecińskiej. Ustalono granice terytorialne prowincji pomorskiej. W skład jej weszły wówczas rejencje: Vorpommern z siedzibą w Szczecinie i Hinterpommern z siedzibą w Koszalinie. W skład rejencji szczecińskiej wchodziły wówczas takie powiaty jak: szczeciński, kamieński, nowogardzki, pyrzycki, stargardzki, woliński, goleniowski, gryfiński, łobeski ${ }^{7}$. Powiat szadzki (czyli stargardzki), obejmował miasta: Ińsko, Suchań, Chociwel, Dobrzany, zaś jego stolicą był Stargard ${ }^{8}$. W 1901 r. wydzielono z powiatu szadzkiego miasto Stargard, jako osobny powiat grodzki. Powiat szadzki ${ }^{9}$ istniał na mapach Niemiec od 1818 aż do $1945 \mathrm{r}^{10}$

Edykt wydany 11 III 1812 r. został wprowadzony w życie w Stargardzie z dniem 24 marca tego samego roku. Edykt o stosunkach obywatelskich, funkcjonujący pod nazwą edyktu emancypacyjnego, dotyczył upełnoprawnienia Żydów, jako obywateli Prus. Warunkiem uzyskania obywatelstwa pruskiego było m.in.: przyjęcie imion i nazwisk niemieckich. Zarządzenie wykonano według określonej instrukcji, która zawierała szczegółowe informacje dotyczące przebiegu i praktycznych wymogów rejestru. Spis miał zostać przeprowadzony przez miejscowe władze policyjne, miał się on odbyć w każdej miejscowości powiatu. Wykonawcami spisów były urzędy powiatowe.

W samym Stargardzie, stolicy powiatu, w 1812 r., według G. Salingera, nazwiska niemieckie przyjęły 73 rodziny $^{11}$. Z kolei J. Grzelak podaje, że w 1812 r. na 8900 mieszkańców Stargardu było 184 Żydów ${ }^{12}$.

${ }^{7}$ Archiwum Państwowe w Szczecinie (dalej:AP Szczecin), A. Poniatowski, M. Knitter, Wstęp do inwentarza zespolu Naczelne Prezydium Prowincji Pomorskiej w Szczecinie 1808-1945, Szczecin 2009, s. 10.

${ }^{8} \mathrm{~W}$ niniejszej publikacji nazwa miejscowości w XIX w. Stargard in Pommern będzie funkcjonowała jako Stargard bez przymiotnika Szczeciński. Jest to zgodne z nazewnictwem niemieckim opisywanego okresu, jak też nazewnictwem współczesnym miejscowości.

${ }^{9}$ Śledząc dzieje ludności żydowskiej na terenie pow. szadzkiego, należy również oprzeć się na literaturze historycznej omawiającej i opisującej historię zarówno tego powiatu, jak i poszczególnych miejscowości wchodzących w skład tego obszaru administracyjnego. P. Schulz, Der Kreis Saatzig und die Kreisfreie Stadt Stargard, Rautenberg 1984; natomiast o Dobrzanach i nie tylko, traktują książki F. Knacka: Beitrage zur Landes - und Volkskunde aus dem Kreise Saatzig in Pommern, H. 1, Jacobshagen 1912; Die Burg Saatzig, Jacobshagen und die pommerschen Koloniegrundungen Friedrichs des Grosen Grabnitzfelde und Constantinopel. Ein Beitrag zur Heimatkunde und Jugendpflege, Jacobshagen 1912; 600 Jahre Jacobshagen, zugleich ein geschichtlicher Beitrag zur Heimatkunde des Kreises Saatzig in Pommern. Festschrift 1336 - 1936, Jacobshagen 1936.

${ }^{10}$ AP Szczecin, Inwentarz Akta Miasta Stargard, oprac. M. Kozłowski, M. Stelmach, J. Podralski, 2013 , s. 7.

${ }^{11}$ G. Salinger, Zur Erinnerung und zum Gedenken. Die einstigen jüdischen Gemeinden Pommerns, t. 3, New York 2006, s. 751-753.

12 J. Grzelak, Żydzi naturalizowani w Stargardzie na podstawie edyktu emancypacyjnego z 11 marca 1812, „Stargardia”, t. 6, Stargard 2011, s. 264. Trzeba zaznaczyć w tym miejscu, że informacje 
Skutkiem rozrastania się miasta i zwiększania się liczby mieszkańców, przeprowadzono szereg inwestycji komunalnych i reform administracyjnych. Miasto zostało podzielone na 13 okręgów miejskich: Ihna, Johann, Marien, Markt, Movius, P. Gröning, Pyritzer, Regierung, Wall, Fr. Wilhelm, Jobst, Louisen, Werder ${ }^{13}$. Większość Żydów mieszkających w Stargardzie zajmowała się handlem i rzemiosłem, w związku z tym niejako naturalnym ich skupiskiem było centrum miasta - rynek i zarazem plac targowy ${ }^{14}$.

Tabela 1

Liczba ludności żydowskiej w powiecie szadzkim w XIX i XX wieku

\begin{tabular}{|c|c|c|c|c|c|c|c|c|c|}
\hline Rok & 1871 & 1880 & 1885 & 1895 & 1905 & 1910 & 1925 & 1933 & 1939 \\
\hline Liczba osób & 753 & 868 & 908 & 835 & 228 & 204 & 148 & 112 & 36 \\
\hline
\end{tabular}

Źródło: D. Szudra, Obraz demograficzny ludności żydowskiej na Pomorzu Zachodnim w latach 1871-1939, [w:] Żydzi oraz ich sąsiedzi na Pomorzu Zachodnim w XIX i XX wieku, pod red. M. Jaroszewicz, W. Stępiński, Warszawa 2007, s. 322.

Liczba mieszkańców wyznania mojżeszowego od początku XIX w. w powiecie szadzkim wzrastała. Największa liczba Żydów w Saatzig Kreis zamieszkiwała w roku 1885 . Wzrost mieszkańców był spowodowany korzystnymi warunkami osiedlania się, poprzedzonymi stosownymi ustawami i edyktami. Wraz z początkiem XX w. liczba ta drastycznie malała w ogólnym rozrachunku liczby ludności, jak i w stosunku do poszczególnych miejscowości. Spadek liczby spowodowany był migracjami (zwłaszcza na zachód, w stronę Berlina), zwiększającego się stopnia asymilacji ludności żydowskiej, jak również narastającego w Niemczech antysemityzmu ${ }^{15}$.

podane przez J. Grzelaka są poparte udokumentowaną kwerendą archiwalną. Natomiast G. Salinger w swoim opracowaniu nie podaje źródła podawanych informacji. Warto dodać, że J. Grzelak w aneksie do swojego artykułu podaje informacje $z$ tabetycznej listy rejencyjnej i akt magistratu, które zostały przełożone do jednej osoby. Tabela obejmuje 13 podpunktów. Zawarte są informacje takie jak, m.in.: imiona dotychczasowe i źródła utrzymania, data i miejsce urodzenia, miejsce zamieszkania i od kiedy, data zawarcia związku małżeńskiego, liczba dzieci. Ostatni 13 podpunkt dotyczy źródła podawanej informacji, w tym przypadku są to Akta Miasta Stargard z kolejnymi sygnaturami akt.

${ }^{13}$ J. Stuch, Rozwój demograficzny Stargardu w latach 1815 - 1846, „Stargardia”, t. 2, Stargard 2002, s. 144.

${ }^{14}$ Tamże, s. 149.

${ }^{15}$ Por. G. Salingera, Zur Erinnerung...; K.D. Alicke, Lexikon der jüdischen Gemeinden im deutschen Sprachraum, München 2009; 
Niestety, nie dysponujemy kompletnymi danymi dla porównania liczby mieszkańców wyznania mojżeszowego w poszczególnych miejscowościach. Ogólnie, na tle całego powiatu, największy wzrost przypada na rok 1849, czyli po wydaniu najistotniejszej uchwały z 23 VII 1847 r., regulującej prawne osadnictwo żydowskie. Liczba ludności żydowskiej poza Stargardem była o wiele niższa. Wynikało to głównie z wielkości tychże miejscowości ${ }^{16}$.

Największy wzrost liczby ludności wyznania mojżeszowego odnotowano w Stargardzie w przeciągu pięciu lat od 1812 r. i wydania edyktu tolerancyjnego z 11 marca do 1817 r. z liczby 184 do 365 osób. Liczba ta zwiększyła się o 599 osób. Wraz ze wzrostem ogólnej liczby mieszkańców miasta w opisywanym okresie zwiększyła się liczba Żydów zamieszkujących Stargard. Natomiast największą różnicę w spadku mieszkańców pochodzenia żydowskiego zanotowano w okresie między latami 1880 a 1913 . Liczba ta zmniejszyła się w ciągu 33 lat o 212 osób. W Chociwlu ${ }^{17}$ najwyższa liczba mieszkańców - Żydów, przypada na rok 1890 - ok. 110 osób.

Wspomniany wcześniej edykt z 1847 r. o ordynacji gminnej spowodował i sprowokował dynamiczny rozwój gmin. Gminy żydowskie poprzez swoją aktywność wytworzyły szereg świadectw swojego istnienia, począwszy od budynków (np. synagogi) skończywszy na cmentarzach. O rozwoju danej gminy, społeczności świadczyły powstające instytucje życia codziennego.

Zgodnie z ordynacją ustawy z 23 VII 1847 r., każdy okręg synagogalny musiał posiadać swoją świątynię. Pamiętać należy jednak, że pod pojęciem synagogi kryły się nie tylko funkcje religijne, a sama synagoga, nie musiała być od razu ogromnym budynkiem. Niemniej, największa synagoga znajdowała się w Stargardzie.

W tym czasie tj. w 1847 r. w Stargardzie mieszkało 260 Żydów. Jest to dość znaczna liczba, w związku z tym wydaje się zasadnym twierdzenie, że przy synagodze musiała znajdować się również mykwa. Mykwy najczęściej były lokowane właśnie w sąsiedztwie synagogi. Z czasem, gdy gmina się powiększała, zaistniała potrzeba wybudowania większej świątyni. Nowa synagoga w Stargardzie została otwarta 28 IX 1913 r., znajdowała się przy ulicy Spichrzowej 14/15. Joachim Stampa zamieścił w książce krótką charakterystykę świątyni, opisując ją

\footnotetext{
${ }^{16}$ E. Olszewski, Stargardzkie ABC, Stargard 2001. J. Stuch, Rozwój demograficzny Stargardu w latach 1815-1846...; tenże, Rozwój demograficzny Stargardu w latach 1846 - 1870, „Stargardia”, t. 3, Stargard 2003.

${ }^{17}$ Chociwel, jako osada została wymieniona po raz pierwszy w 1321 r., w 1378 r. Chociwel został otoczony murami obronnymi. Od 1600 r. miasto funkcjonowało na prawie lubeckim. Ludność głównie zajmowała się rolnictwem i rzemiosłem, odbywały się tu 4 jarmarki rocznie. Ważnym momentem było wybudowanie w 1843 r. szosy łączącej Chociwel ze Stargardem, a 1859 r. linii kolejowej, która biegnąc ze Stargardu do Białogardu, przecinała Chociwel. Pierwsza wzmianka o Żydach w ogóle (tutaj dokładnie chodzi o bogatego mieszkańca wyznania mojżeszowego) w Chociwlu pojawia się w $1705 \mathrm{r}$. AP Szczecin, B. Frankiewicz, Wstęp do Inwentarza zespolu akt Akta miasta Ińsko (Magistrat Nörenberg 1564-1938), Szczecin 1967, s. 1.
} 
jako budowlę wzniesioną w stylu orientalistycznym, z żółtą fasadą i ceglanymi obramowaniami ${ }^{18}$.

W wyniku Nocy Kryształowej dach synagogi uległ poważnemu zniszczeniu. Chociaż sam budynek nie spłonął, to stanowił zagrożenie dla osób znajdujących się wewnątrz i obiekt został rozebrany ${ }^{19}$.

Pierwszym rabinem zatrudnionym przez Gminę w Stargardzie był dr Caro w 1857 r., wtedy liczyła ona ok. 397 członków. W późniejszych latach zatrudniono jeszcze paru dodatkowych urzędników ${ }^{20}$. Chociwel nie posiadał tradycyjnej synagogi, tj. wolnostojącego budynku, a tzw. salę modlitw usytuowaną w domu przy ulicy Stargarder Straße 18 (ul. Stargardzka, obecnie ul. Henryka Dąbrowskiego) ${ }^{21}$. Dobrzańska synagoga znajdowała się przy ulicy Bergstraße (Podgórna) ${ }^{22}$. Od początku XX w. liczba Żydów mieszkających w Dobrzanach zmniejszała się, a co za tym idzie, utrzymanie synagogi i zapotrzebowanie na korzystanie z niej malało. W 1936 r. Gmina odsprzedała budynek ślusarzowi Wilhelmowi Borckowi ${ }^{23}$. Ińska synagoga stała przy ulicy Schulstraße 2, natomiast suchańska świątynia znajdowała się przy ulicy Judengaße $e^{24}$.

W latach 1870 - 1911 niewielka gmina żydowska w Suchaniu zatrudniała również urzędników pełniących funkcje kantora i nauczyciela, odpowiednio A. Rosenow i N. Levy25.

Żydzi bynajmniej nie pozostawali zamknięci w ramach swojej gminy i współwyznawców. Poprzez swoją działalność i funkcjonowanie wpływali m.in. na rozwój przestrzenny miejscowości (np. budowa synagogi). Procesy emancypacyjne i akulturacja umożliwiały intensywniejsze zaznaczenie swojej obecności na wszystkich płaszczyznach życia społecznego. Dziedziną integracji społecznej na linii państwo (goje) - Żydzi było szkolnictwo. Jak podaje Salinger, rabini stargardzcy uczyli w Kolegium Gröninga. Szkoła powstała w wyniku realizacji testamentu burmistrza Stargardu Petera Gröninga, który przeznaczył swój majątek właśnie na szkołę. Szkoła rozpoczęła działalność 28 IX 1633 r., jako protestancka szkoła. W 1714 r. szkołę przekształcono na wyższą szkołę i z prawem do nadawania stopni doktorskich i profesorskich ${ }^{26}$. W 1788 r. wprowadzono w szkole egzamin maturalny. W owym czasie jedynie trzy szkoły na Pomorzu

\footnotetext{
18 J. Stampa, Stargard in Pommern und Seine Gotteshäuser, 1975, s. 27.

${ }^{19}$ Tamże.

${ }^{20}$ Tamże.

${ }^{21}$ F.R. Barran, Städte - Atlas Pommern, Leer 1993, s. 50.

${ }^{22}$ Tamże, s. 60.

${ }^{23}$ M. Grzenda, Synagogi, domy modlitwy inne. Dobrzany, http://www.sztetl.org.pl/pl/article /dobrzany/11,synagogi-domy-modlitwy-i-inne/175, synagoga-ul-podgorna-/, (dostęp: 12.12.2013).

${ }^{24}$ F. R. Barran, Städte..., s. 84, 132.

${ }^{25}$ G. Salinger, Zur Erinnerung..., t. 3, s. 859; Adressbuch Stargard in Pommern 1911, Stargard in Pommern, s. 214.

${ }^{26}$ S. Falbe, Geschichte des Gymnasiums zu Stargard, Stargard in Pommern 1831, s. 72.
} 
Zachodnim mogły przeprowadzać taki egzamin (w tym stargardzka uczelnia) ${ }^{27}$. Szkoła przeżyła ożywienie, gdy połączono trzy stargardzkie szkoły (Collegium Groeningianum, Szkołę Ratuszowa i Szkotę Realna) w Königiches und Gröningsches Stadtgymnasium ${ }^{28}$.

Tabela 2

Liczba uczniów w latach 1864-1934

\begin{tabular}{|c|c|c|c|c|c|c|}
\hline Rok & Ogólem & Ewangelicy & Katolicy & Żydzi & Rejonowi & Zamiejscowi \\
\hline $1864 / 1865$ & 445 & 385 & 3 & 57 & 259 & 186 \\
\hline $1874 / 1875$ & $402 / 91$ & $377 / 77$ & $2 / 1$ & $23 / 13$ & $177 / 81$ & $225 / 10$ \\
\hline $1884 / 1885$ & $355 / 85$ & $307 / 72$ & $11 / 2$ & $27 / 11$ & $204 / 77$ & $150 / 8$ \\
\hline $1894 / 1895$ & $229 / 55$ & $206 / 39$ & $4 / 1$ & $19 / 15$ & $148 / 51$ & $81 / 4$ \\
\hline $1904 / 1905$ & $322 / 67$ & $293 / 61$ & 5 & $24 / 6$ & - & - \\
\hline $1909 / 1910$ & $318 / 56$ & $291 / 51$ & $10 / 2$ & $16 / 3$ & $197 / 48$ & $121 / 8$ \\
\hline $1913 / 1914$ & $320 / 58$ & $303 / 51$ & $5 / 3$ & $12 / 4$ & - & - \\
\hline $1924 / 1925$ & 247 & 227 & 6 & 14 & - & - \\
\hline $1933 / 1934$ & 250 & 238 & 6 & 3 & 163 & 87 \\
\hline
\end{tabular}

Źródło: G. Salinger, Zur Erinnerung und zum Gedenken. Die einstigen jüdischen Gemeinden Pommerns, t. 3, New York 2006, s. 765.

Najwięcej młodzieży pochodzenia żydowskiego uczęszczało do szkoły w roku szkolnym 1864/1865 zamykając się liczbą 57 osób. Natomiast w roku szkolnym 1933/1934 w Gimnazjum Gröninga uczyły się już tylko 3 osoby wyznania mojżeszowego. Wynikało to $\mathrm{m}$. in. $\mathrm{z}$ dojścia nazistów do władzy.

Wprowadzony obowiązek służby wojskowej stał się jednym kolejnych obszarów integracji społecznej. Wiadomo, że Żydzi stargardzcy brali czynny udział w I wojnie światowej. Salinger podaje nawet personalia 17 uczestników tych walk, podobnie wymienia dwóch mieszkańców Suchania, którzy polegli w Wielkiej Wojnie ${ }^{29}$.

${ }^{27}$ J. Zenker, Stargard. Klejnot na pomorskim szlaku, Stargard 2006, s. 96.

${ }^{28}$ M. Majewski, A. Śliwińska, Wymarła tradycja. Collegium Groeningianum, [w:] Wspólne dziedzictwo. Ze studiów nad stosunkiem spuścizny kulturowej na ziemiach zachodnich i pótnocnych, pod red. M. Mazur, Poznań 2000, s. 459.

${ }^{29}$ G. Salinger, Zur Erinnerung..., t. 3, s. 762. 
$\mathrm{Na}$ cmentarzu w Stargardzie został wystawiony pomnik ku czci poległych żołnierzy podczas I wojny światowej. Pomnik w formie stożkowej ma wypisane inskrypcje w języku hebrajskim, rosyjskim i niemieckim, z datami 1914-1921 ${ }^{30}$.

Jedną z konsekwencji I wojny światowej były migracje ludności, także żydowskiej. Mieszkańcy stargardzkiej Gminy wyjeżdżali do większych miast niemieckich. Natomiast w związku ze zmianami granic po wojnie, do Stargardu zaczęli przyjeżdżać Żydzi z terenów, które znalazły się na obszarze państwa polskiego, tj. okolic z Poznania i Prus Zachodnich.

Cmentarze, jako szczególne miejsca tradycji i pamięci żydowskiej, były pod szczególną opieką gmin. W Dobrzanach cmentarz znajdował się przy Saatziger Chausee Straße (dzisiejsza ulica Adama Mickiewicza) ${ }^{31}$. Iński cmentarz znajdował się między dzisiejszymi ulicami Młynarską i Armii Krajowej ${ }^{32}$. Również w Suchaniu znajdował się cmentarz, którego nieliczne macewy do dziś wystają niepewnie z ziemi. Największy cmentarz istniał w Stargardzie. Wzmianki o jego istnieniu mamy już od drugiej połowy lat sześćdziesiątych XVII w. Ostatni pochówek na nim miał odbyć się w roku 1835 bądź 1838 . W roku 1938 cmentarz, liczący sobie wówczas ponad 250 lat, został całkowicie zniszczony. Jego obszar o powierzchni 0,3 ha porósł roślinnością i zamienił się w zdziczały park, a następnie przerobiono go na tereny zielone ${ }^{33}$.

W lutym 1940 r. NSDAP wywiozło w pobliże Lublina w Generalnej Guberni żydowskie rodziny ze Szczecina, Stargardu i okolicznych miejscowości. Zniszczenia powojenne miasta wyniosły $60-70 \%$, ale Starówka była zniszczona niemal w 90\%. Po II wojnie światowej Stargard znalazł się na terenie Polski. Władze polskie rozpoczęły tu działalność 23 III 1945 r. Rozpoczęła się akcja osadnicza i odbudowa miasta. Jednak ludność żydowska już tutaj nie powróciła ${ }^{34}$.

9 IX 2013 r. jeden z mieszkańców Stargardu wystosował pismo do Prezydenta Miasta Stargardu, w którym czytamy:

Zwracam się z pytaniem o plany upamiętnienia cmentarza wyznania mojżeszowego i tym samym miejsca spoczynku przedwojennej społeczności żydowskiej Stargardu, która miała niewątpliwie wielki wpływ na rozwój miasta ${ }^{35}$.

\footnotetext{
${ }^{30}$ Cmentarz Wojenny w Stargardzie przy ul. Reymonta.

${ }^{31}$ F. R. Barran, Städte..., s. 60.

${ }^{32}$ Tamże, s. 84.

${ }^{33}$ M. Grzenda, Cmentarze. Stargard, http://www.sztetl.org.pl/pl/article/stargard-szczecinski/12, cmentarze/6644,cmentarz-zydowski/, (dostęp: 12.12.2013).

${ }^{34}$ M. Szauman, Wplyw Żydów na rozwój gminy Stargard, www.mmstargard.pl/wplyw-zydow-na-rozwoj-gminy-stargard, (dostęp: 10.11.2014).

35 http://www.sztetl.org.pl/pl/article/stargard-szczecinski/19, aktualnosci/42441,09-09-2013-r-pismo -w-sprawie-cmentarza-zydowskiego-w-stargardzie-szczecinskim-/, (dostęp: 01.09.2014).
} 
I choć w samym mieście widoczne znamiona społeczności żydowskiej ograniczają się do drogowskazu turystycznego, połamanej macewy w Muzeum Miejskim i cukiernicy z inicjałami hebrajskimi, to mimo wszystko, gdzieś w świadomości mieszkańców temat Żydów zamieszkujących Stargard w jakiś sposób funkcjonuje. Objawia się to chociażby takimi petycjami mieszkańców, czy pojawiającymi się co pewien czas artykułami. Zobaczymy, czym w przyszłości zaowocuje owo zainteresowanie.

Okres XIX i XX wieku to intensywny czas rozwoju społeczności żydowskiej na terenie Pomorza Zachodniego, ale także na obszarze całych Prus. Opisując historię i rozwój tego regionu, należy pamiętać o różnorodności kulturowej i społecznej, którego jednym z elementów była społeczność żydowska. Tendencja do opisywania społeczności żydowskich w skali mikroregionów jest szansą na zachowanie pamięci i wzbogacenie wiedzy nie tylko z obszarów dużych miast takich jak Szczecin, ale i jeszcze mniejszych, jak choćby Stargard, gdzie Żydzi współtworzyli jego historię i przestrzeń przez parę setek lat.

Justyna Żukowska-Łyko

\section{JEWS IN SZADZKO COUNTY'S STARGARD IN $19^{\text {TH }}$ AND $20^{\text {TH }}$ CENTURY - CAPTURING THE ALREADY ABSENT}

The first cases of Jewish settlement in Pomerania, we can note in the $13^{\text {th }}$ century. One of the common activities of the Jews was trade. In fact, the $19^{\text {th }}$ century brought about a major change in the legal position and the settlement of Jews in Pomerania. Issued edict on 11 March 1812. Jews legitimized as citizens of Prussia. In order to obtain Prussian citizenship was: acceptance of German names. The largest increase in the number of Jews in Stargard recorded between 1812-1817 year with the number of 184 to 365 people. The first rabbi employed by the Municipality in Stargard was Dr. Caro in 1857. Then Municipality consisted of approx. 397 members. After World War II, the Polish authorities have started action settlement and reconstruction of the city. The Jewish population has not recovered. 